City University of New York (CUNY) CUNY Academic Works

\title{
Pricing Climate Change Risk in Corporate Bonds
}

Elsa Allman

CUNY Bernard M Baruch College

\section{How does access to this work benefit you? Let us know!}

More information about this work at: https://academicworks.cuny.edu/bb_pubs/1171

Discover additional works at: https://academicworks.cuny.edu

This work is made publicly available by the City University of New York (CUNY).

Contact: AcademicWorks@cuny.edu 


\title{
Pricing Climate Change Risk in Corporate Bonds
}

\author{
By Elsa Allman*
}

July 2020

\begin{abstract}
This paper examines whether corporate bondholders price climate change risk. I find that firms exposed to higher sea level rise (SLR) across U.S. branch locations pay a premium when issuing bonds. Specifically, a one standard deviation increase in a firm's SLR exposure is associated with a $2 \%$ increase of average yield spreads equivalent to 4 basis points. This effect is more pronounced for firms in industries vulnerable to extreme weather conditions, which are less spatially diversified, and issuing bonds with maturities ranging from 5 to 10 years. In addition, I find no evidence that credit rating agencies account for SLR exposure at issuance, corroborating anecdotal evidence of a recent interest for climate risks. Given the increasing awareness regarding the economic cost of climate change, these results collectively have important financial implications for firms considering where to locate branches in areas exposed to sea level rise as well as implications for policymakers concerned by the possibility of a climate credit crunch.
\end{abstract}

Keywords: Climate Risk, Corporate Bonds, Sea Level Rise

JEL Classification: Q54, G14, G24 L51

* Ph.D. Candidate, Baruch College, The Zicklin School of Business, 55 Lexington Avenue, New York, NY 10010, USA. E-mail: Elsa.Allman@baruch.cuny.edu 


\section{Introduction}

In January 2019, California's largest utility company filed for Chapter 11 in what an article in the Wall Street Journal designated as the "first climate-change bankruptcy" (Gold, 2019). Pacific Gas \& Electric's bankruptcy resulted from liabilities created by massive wildfires following an extended period of drought. This climate change bankruptcy will likely not be the last (Macwilliams et al., 2019). Firms are increasingly exposed to physical climate risks including the occurrence of extreme weather events (e.g. hurricanes) and changing climatic conditions (e.g. rising sea levels). As global temperatures rise, droughts, heat waves, floods, cold spells, and other extreme weather events are becoming more severe and frequent, but also more costly. Under a warming scenario of $2{ }^{\circ} \mathrm{C}$, economic damage from climate change could reach $\$ 69$ trillion by the year 2100 (IPCC, 2018).

The growing threat of climate risk is an increasingly important concern for investors. A survey by (Krueger et al., 2020) suggests that $30 \%$ of institutional investors consider physical climate risks important for portfolio management decisions. However, it is unclear whether these considerations are priced in asset valuations. According to a report by the Rhodium Group (2019), the physical risks of climate change are "clear, present and underpriced.” Norges Bank Investment management, one of the largest investors funds, concludes that "capital markets do not fully price climate risk" in its 2019 annual Responsibility Report. ${ }^{1}$ Corporate disclosure of climate risk by companies is limited (Matsumura et al., 2017), which hinders investors' capacity to estimate the financial implications and magnitudes of these risks. However, policymakers are increasingly aware of the threat that climate change poses for the stability of the financial system (Carney, 2015). Financial markets play a key role in mitigating costly damage from climate change. By pricing climate change risk today, markets can reduce the possibility of wealth transfers between uninformed and sophisticated agents, as well as reduce the future likelihood of extreme price variation (Bernstein et al., 2019).

Empirical evidence relating to the pricing of climate change risk is mixed. In spite of a growing strand of the literature documenting that asset prices, including real estate, equity shares or municipal bonds, account for climate change risks (Bernstein et al., 2019; Kruttli et al., 2019; Painter, 2020), there is also proof of underpricing (Griffin et al., 2019; Bertolotti et al., 2019) and a lack of anticipation of these long-term and highly uncertain risks (Bernstein et al., 2019; Hong et al., 2019). In addition, heterogeneity of climate change

\footnotetext{
${ }^{1}$ Responsible investment 2019, Norges Bank Investment Management.
} 
beliefs are found to be a significant determinant of real estate prices (Baldauf et al., 2020; Bernstein et al., 2019) and credit spreads of municipal bonds (Goldsmith-Pinkham et al., 2020).

In this paper, I examine whether the corporate bond market prices climate change risk, which refers to the threat of damage, injury, liability, loss, or any other harm that could be caused by climate-related events (Flammer et al., 2019). To my knowledge, it is the first, to assess the importance of climate risk exposure for corporate bond investors. Corporate bonds reflect investors' expectations on future outcomes, which may include their concerns for climate risks. Contrary to stocks, bonds are particularly exposed to large downside risks. Given their payoff profile, the likelihood of large negative shocks is an important factor for prices, which reflect an issuer's capacity to repay its debt (Goldsmith-Pinkham et al., 2020). However, the long run and uncertain nature of climate change risk makes its pricing an unanswered empirical question (Bernstein et al., 2019; Brock and Hansen, 2018).

A challenge in examining corporate climate change exposure, as opposed to municipalities, is that corporations decide where to establish their business. Firms can reduce their exposure to climate change risk by choosing areas less exposed to extreme weather conditions and sea level rise, and can change locations if staying in a given area becomes too costly. However, findings on whether firms actually migrate to safer areas after natural hazards is mixed (Kocornik-Mina et al., 2015; Indaco et al., 2019). In addition, firms can diversify their climate risk exposure by establishing a presence in more than one location, a feature that needs to be considered in light of the potential costs induced by relocation, and the need to be close to networks of customers, suppliers, and investors (Jiang et al., 2019).

To account for the spatial distribution of corporate issuers, I compute weighted measures of physical climate risk exposure based on county-level shares of sales, number of employees, and branches. This allows me to capture the extent of a firm's geographic footprint as well as to account for the possibility that a given firm changes the location of its branches. To measure climate change risk, I focus on the risk of rising sea levels which is a major threat to coastal cities. According to the National Oceanic and Atmospheric Administration (NOAA), global sea levels have risen by about 21-24 centimeters since 1880, and are expected to rise at least 30 centimeters above 2000 levels by the end of the century. ${ }^{2}$ However, regions are impacted differently by this rise, depending on local factors such as erosion or ground settling. I exploit regional variation in sea level rise

\footnotetext{
${ }^{2}$ This is equivalent to $8-9$ inches since 1880 and 12 inches by the end of century.
} 
(SLR) exposure by using local measures of expected mean annual losses from sea level rise as a percentage of GDP obtained from (Hallegatte et al., 2013). These estimated losses, which are computed for coastal cities, are based on an expected $40 \mathrm{~cm}$ rise of sea levels in 2050. Following Painter (2020), I obtain county-level exposure to sea level rise by mapping cities to counties, and assigning zero to counties with no expected loss.

To assess whether bondholders price climate change risk, I first examine the effect of firms' sea level rise exposure on bond yields and credit ratings at issuance. Focusing on a sample of 6,276 bonds issued by 872 U.S. public firms between 2010 and 2018, I find that SLR exposure significantly affects yield spreads. The results are qualitatively similar after using alternative weighting schemes in calculating SLR exposure. A one standard deviation increase in sales-weighted exposure to sea level rise is associated with a 4 basis points increase in yield spread, equivalent to a $2 \%$ increase of average yield spreads, after controlling for key determinants of bond prices (maturity, credit rating, amount issued), issuer characteristics, as well as including year and industry fixed effects. In addition, I find that credit ratings do not appear to capture climate change risk at issuance. These results corroborate anecdotal evidence suggesting that credit agencies are slow to account for these risks (Flavelle, 2019). In particular, a report by the Center for International Environmental Law (CIEL, 2015) alerts on the possibility of a repeated global credit crisis if credit rating agencies continue to miscalculate climate change risk.

The effect of SLR exposure on bond yields holds in a variety of robustness tests, such as excluding coastal counties assigned a zero SLR exposure and excluding inland counties. To address concerns regarding spurious correlations, I conduct a placebo test which assigns SLR exposure to neighboring inland counties that are likely to face similar economic conditions. The results of this test are negative and insignificant, providing corroborating evidence that SLR exposure is priced in corporate bonds. In addition, I find that the results hold after applying inverse propensity weighting, with propensity scores obtained from a logit regression relating the probability of having above-median levels of SLR exposure, issuer characteristics, and HQ county-level control variables.

I next examine the role of spatial dispersion as captured by the number of U.S. counties in which a firm is located. Although some firms are located in a single area, others have branches in more than 2,000 different counties. I first verify whether the effects of SLR exposure are not driven by firms highly spatially diversified by excluding those in the top decile of spatial distribution, with a presence in over 802 counties. The estimated 
effects on yield spreads are lower for firms less geographically diversified, as well as statistically significant. I then interact SLR exposure with the number of counties. I find that higher spatial dispersion reduces the cost of climate risk, indicating that geographic diversification mitigates the impact of climate risk exposure, although not significantly. I also examine whether the cost of climate risk is driven by industries vulnerable to floods and extreme weather conditions, either because they rely on physical assets or involve activities that are dependent on good weather conditions. I find that the results are concentrated in such industries, and in particular for firms in the Communication and Energy sectors. Finally, I find that investors price climate risk in bonds with maturities ranging from 5 to 10 years, consistent with the findings of Krueger et al. (2020) that a majority of institutional investors believe that climate risks will materialize in less than 10 years.

This study contributes to the growing literature examining the role of financial markets in pricing climate change risk by focusing on a key market for U.S. firms and investors: the U.S. corporate bond market. More than double the size of the municipal bond market, it is the primary source of financing for U.S. firms (Bhojraj and Sengupta, 2003), much larger than the stock market. ${ }^{3}$ In addition, corporate bondholders bear substantially more default risk than municipal bondholders (Moody's, 2017). ${ }^{4}$ Given that corporate climate risks are fundamentally downside risks, accounting for these risks is a key concern for investors. My findings complement the work of Painter (2020) and Goldsmith-Pinkham et al. (2020), who show that SLR is priced in municipal bonds.

I also contribute to the nascent literature on the financial consequences of climate risk for firms (e.g., Addoum et al., 2019; Huang et al., 2018; Hugon and Law, 2019; Pankratz et al., 2019; Hong et al., 2019). In particular, contrary to Jiang et al. (2019), I examine SLR exposure at the branch level rather than solely at headquarters, allowing me to capture a fuller picture of corporate SLR exposure. Jiang et al. (2019) find that firms located in areas with higher SLR exposure are penalized when taking out long-term loans: a one standard deviation increase in HQ sea level rise is associated with an additional 4.3 basis points loan spread. Similarly, I find that firms pay bondholders a 4 basis points yield spread premium for an additional standard deviation of SLR exposure. These results have important implications for firms' choice in establishing branches in locations more or less exposed to sea level rise, and wishing to cut down their cost of debt.

\footnotetext{
${ }^{3}$ According to S\&P Global, outstanding U.S. corporate debt instruments rated by S\&P Global Ratings amount to $\$ 9.3$ trillion as of Jan. 1, 2019, whereas the municipal market is approximately $\$ 3.8$ trillion.

${ }^{4}$ The five-year municipal default rate since 2007 was $0.15 \%$, whereas the five-year global corporate default rate was $6.92 \%$ since 2007.
} 
Finally, this study adds to the extensive literature on the determinants of corporate bond issuance costs (e.g., Flannery et al., 2012). It relates to Amiraslani et al. (2017) and Jiraporn et al. (2014) which find that a firm's environmental performance is viewed positively by bondholders and improves credit ratings. It also complements the work of Seltzer et al. (2020) which find that corporate bond prices are determined by climate regulatory risks and firms' environmental profiles. In contrast to these papers, I focus on firms' climate change risk as opposed to firms' environmental footprint, as captured by environmental, social and governance (ESG) scores. Firms across all industries and countries are exposed to climate change risk regardless of their emission levels and contribution to global warming. ESG scores, on the other hand, reflect an externality cost driven by corporate behavior, such as a firm's carbon footprint or use of resources.

The rest of the paper is organized as follows. Section 1 reviews the existing literature and describes the motivation for examining whether corporate bondholders price climate change risk. Section 2 describes the empirical setting, specifying how climate change risk is measured based on branch location and county exposure to sea level rise. Section 3 presents the main results and conducts a series of robustness tests. Before concluding, section 4 considers the impact of spatial dispersion, industry heterogeneity, and investors' risk horizon on the SLR and bond pricing relationship.

\section{Pricing Climate Change}

Institutional investors believe that climate risks have significant financial implications for portfolio firms (Krueger et al., 2020). Their financial materiality is regarded as being somewhere between "important" and "fairly important". Physical climate risks, i.e. direct costs resulting from changes in the climate, are ranked highest in term of materiality, followed by transition risks, which include regulatory risk (i.e., the cost of new policies such as limited carbon emissions), and technological risks (i.e., the threat of technological disruptions). In addition, climate change has been a top sustainability shareholder proposal in recent years, with increasing shareholder support and approval rates (Flammer, 2015; Flammer et al., 2019).

A growing literature focusing on the financial consequences of climate risk corroborates survey responses and shareholder proposals by providence further evidence on the financial materiality of climate risk. Addoum et al. (2019) find that extreme temperature impacts earnings in over $40 \%$ of industries in the U.S., in line with Huang et al. (2018). Exploiting regional temperature variation around corporate headquarters, Hugon and Law (2019) find that a one degree Celsius increase in temperature is associated with a \$1.6 mil- 
lion decrease in earnings for a median-sized firm. Pankratz et al. (2019) show that increasing exposure to high temperature and floods reduces revenues and operating income, while Hong et al. (2019) predict poor profit growth for food companies in countries vulnerable to long-term drought.

However, evidence relating to the pricing of climate risk in financial assets is mixed even though recent asset pricing models highlight the importance of climate risks as a long-run risk factor. Bansal et al. (2019) argue that if rising temperature has a long-run impact on the aggregate economy, it should be reflected in current equity prices. Forward-looking capital markets are important to mitigate the impact and cost of climate change but they suffer from the challenges posed by modeling uncertainty Brock and Hansen (2018).

Focusing on the real estate market, Bernstein et al. (2019) find that homes exposed to sea level rise sell at a discount, contrary to Murfin and Spiegel (2020) which find limited price effects. Baldauf et al. (2020) argue that the effect of sea level rise on house prices depends on beliefs about climate change. Beliefs are also found to affect loan officers' mortgage lending decisions, especially in counties heavily exposed to the risk of sea level rise (Duan and Li, 2019).

Examining equity markets, Hong et al. (2019) show that they do not anticipate the effects of predictable worsening drought conditions on food companies until they materialize, while Kruttli et al. (2019) find that extreme weather is reflected in stock and option market prices. Griffin et al. (2019) demonstrate that equity markets recognize but underprice physical climate risk, consistent with forming biased expectations of future equity returns. This is consistent with Bertolotti et al. (2019), which show that the physical climate risks of 269 publicly listed U.S. utilities, based on the physical location of their plants, property and equipment, are underpriced in equity markets.

Municipal bond investors in the U.S. are also aware of the risks posed by climate change (Nauman, 2020). Painter (2020) finds that long-term municipal bonds include the cost of climate change risks, whereas Goldsmith-Pinkham et al. (2020) observe evidence of pricing as of 2011 across bond maturities. Contrary to municipalities, firms have the possibility to relocate and reduce exposure to sea level rise. Jiang et al. (2019) show that firms' cost of long term loans is affected by sea level rise exposure, especially for firms which cannot easily relocate or diversify their SLR exposure.

The object of this paper is to examine whether bondholders price climate change risk. Bond prices reflect investors' expectations of future outcomes, including potentially long-run and uncertain risks such as 
climate risks. Given the importance of physical climate risks for investors, I hypothesize that corporate bonds are issued at a premium to account for the future economic cost of sea level rise. By choosing the location of their branches, firms are exposed heterogeneously to the rise of sea levels. Higher SLR exposure leads to a higher risk of value-destructive flooding and storm surges, which in turn increases probabilities of default, a risk born by corporate bondholders.

Firms, contrary to cities, have the possibility to "run-away" from climate risk (Jiang et al., 2019) by either relocating or diversifying their risk. Given that my setting accounts for changes in branch locations, I examine the choice of firms to locate in multiple counties, thereby diversifying their SLR exposure. In particular, I hypothesize that higher spatial diversification will reduce the cost of SLR risk. In addition, certain business activities are more impacted by weather and climate change than others. Extreme weather events can either damage assets thereby reducing corporate profitability, or disrupt business operations which may lead to operating losses. I therefore hypothesize that the investors will require a higher yield spread for firms in industries vulnerable to extreme weather conditions (Huang et al., 2018), such as energy, healthcare, utilities, agriculture, food manufacturing, business services and transportation.

Although sea level rise is by essence a long-term risk, Goldsmith-Pinkham et al. (2020) argue that SLR exposure can affect credit spreads through the short-run risk of flooding due to more severe storms. The authors find that SLR is priced in municipal bonds across maturities starting at the end of 2011. In contrast, Painter (2020) finds that SLR exposure is solely priced in bonds with long-term maturities, as early as 2007. Given that a majority institutional investors believe that climate risks will materialize in less than 10 years, I hypothesize that corporate SLR exposure is priced in bonds with maturities in line with these beliefs.

I also verify whether credit rating agencies incorporate SLR exposure when providing bond ratings at issuance. Although there is evidence that credit ratings are lower for firms with poor environmental performance and with high regulatory risk (Seltzer et al., 2020), it is unclear whether credit rating agencies adequately capture physical climate risk. In particular, while there is evidence that firms' carbon footprint increases credit risk (Capasso et al., 2020), there is no evidence yet linking SLR exposure and credit risk. In addition, anecdotal evidence suggests that the interest of credit rating agencies for climate change risk is relatively recent. I therefore hypothesize that SLR exposure will not affect at-issue credit ratings. 


\section{Empirical Setting}

In this section, I describe the data sources and methodology used to construct a sample of 6,276 U.S. corporate bonds issued between 2010 and 2018. I then describe how I obtain issuer sea level rise exposures based on corporate geographic location, before providing key summary statistics.

\subsection{Corporate Bonds and Issuer Characteristics}

Corporate bond data is obtained from the Mergent fixed income securities database (FISD), which is a comprehensive data source for U.S. corporate bond issues. FISD provides issue dates, yields, prices, bond maturities, coupon rates, amounts issued, and credit ratings. I obtain all bonds issued between 2010 and 2018 for which the issuer's country of domicile is the U.S., excluding non-standard corporate bonds (e.g. convertible or Yankee bonds) and keeping solely bonds with fixed coupons. Yield spreads are obtained by matching each bond to U.S. treasury bonds with similar maturities. For this purpose, I obtain monthly treasury bond data from the Federal Reserve (FRB H15 release) for maturities of one month, 3 month, 6 month, one year, 2 years, 3 years, 5 years, 7 years, 10 years, 20 years and 30 years. Matching bond yields are obtained by interpolating yields in between each year bracket. Bonds with negative yields are removed from the sample. Credit ratings are transformed to numerical values by assigning each rating to a number ranging from 1 , for the lowest rating (D), to 22 for the highest rating (AAA). The primary source of credit ratings is S\&P. If it is unavailable, I use ratings from Moody's or Fitch.

Bond issues are merged with Compustat, first by matching the first six digit CUSIP identifiers, and second, by matching names of corporate entities using fuzzy matching and manual matching. Compustat provides balance sheet data for public companies allowing for the construction of issuer-year level variables including size, leverage, return on assets (ROA), market-to-book (MtB), and the share of property, plants and equipment to total assets (PPE).

\subsection{Measuring Climate Change Risk}

Rising sea levels is a critical consequence of climate change and global warming. As ocean temperatures rise, water expands, and as air temperature increases, melting of ice land such as glaciers adds water to the oceans. According to the NOAA, global mean sea level in 2018 was 8.1 centimeters ( 3.2 inches) above the 1993 average, and sea levels continue to rise at a rate of about one-eighth of an inch per year. 
In the U.S., almost $40 \%$ of the population lives in relatively high population-density coastal areas, where sea level plays a role in flooding, shoreline erosion, and hazards from storms. Rising seas threaten infrastructure necessary for local jobs and regional industries by increasing coastal flood risk. Nuisance flooding, which is disruptive and expensive for local economies albeit not dangerous, is 2 to 9 times more frequent than it was 50 years ago. In addition, higher water levels mean that sever storms, such as Hurricane Katrina that hit the Gulf Coast in August 2005, push farther inland and become a larger threat for coastal economies.

Sea levels will continue to rise with global warming, but it is unclear by how much. Future sea level depend on the rate of future carbon dioxide emissions and temperature rise, as well as on the melting rate of glaciers and ice sheets. According to Sweet et al. (2017), global mean sea level is likely to rise 30 centimeters above 2000 levels before the end of the century, even if greenhouse gas emissions follow a relatively low pathway in coming decades. Scenarios with highest greenhouse gas emissions predict sea level rise could be as high as 2.5 meters above 2000 levels by 2100. Others, such as Hansen et al. (2015), predict that end-ofcentury sea level rise will be negligible.

Furthermore, there is regional variation in terms of sea level rise exposure due to geographic factors, such as where ice is melting or whether tectonic movements cause land to rise or sink. In the U.S., the fastest rates of sea level rise are occurring in the Gulf of Mexico from the mouth of the Mississippi westward, followed by the mid-Atlantic. Sweet et al. (2017) expect sea level rise along the coasts of the U.S. Northeast to be greater than the global average. Krasting et al. (2016) point out the vulnerability of the U.S. east coast to near-future sea level rise.

In this paper, I use county-level measures of expected economic losses from sea level rise following Painter (2020). SLR captures potential economic damage stemming from climate-induced sea level rise. Focusing on major coastal cities, it is equal to the expected mean annual loss from sea level rise as a percentage of city GDP. Estimated losses are predicted by Hallegatte et al. (2013) based on a $40 \mathrm{~cm}$ rise in sea level in 2050. County-level losses are obtained by mapping cities to counties. Inland counties and coastal counties for which there is no predicted estimate of losses are assigned a risk of zero (Figure 1).

[Figure 1 about here]

Table 3 ranks cities (and counties) from highest to lowest exposure to sea level rise. SLR is highest in Orleans Parish, where a rise of $40 \mathrm{~cm}$ of sea levels in 2050 is predicted to cause losses of $1.479 \%$ of GDP. 
Santa Clara, CA, is the coastal county with the least expected loss due to rising sea levels $(0.001 \%)$.

[Table 3 about here]

\subsection{Determining Corporate Geographic Location}

To determine a firm's geographic footprint, I obtain information on the location of establishments, as recorded in Infogroup's Historical Business Database, available in WRDS. Infogroup gathers location-related business data from various public data sources such as local yellow pages, white page directories, credit card billing statements, and public records. They also makes phone calls to update data on establishments, such as the number of full-time equivalent employees. Branch-level data allows to gauge the geographic distribution of firm's operation (Barrot and Sauvagnat, 2016; Pan et al., 2019; Yang, 2018; Baker et al., 2020). Parent companies from Infogroup are matched by name to Compustat, which allows the identification of branch locations for each issuer.

I first aggregate information on sales, employees, and the number of branches each year to the issuercounty level. I then calculate the fraction of a firm's sales, employees and branches in a given county. A firm-year climate change risk measure, $S L R_{i, t}$, is obtained by applying these weights to the sea level rise exposure associated with the county where at least one branch is located, as follows:

$$
S L R_{i, t}=\sum_{c=1}^{C} W e i g h t_{i, t, c} * S L R_{c}
$$

where $W e i g h t_{i, c, t}$ is either the fraction of sales, employees or branches, $\mathrm{i}$ is the bond issuer, $\mathrm{c}$ is the county where the issuer is located, and $t$ is the year of reporting. Bond issuers have branches located in 3,117 counties across the U.S., with some firms more geographically diversified than others. On average, firms have branches located in 251 different counties (Table 2).

I also identify the state and county of corporate headquarters (HQ) from SEC filings using 10-X header data $^{5}$. This data is made available from 1994-2018 by the Notre Dame Software Repository for Accounting and Finance (SRAF) ${ }^{6}$. Corporate headquarters are included in Infogroup and account for $60 \%$ of employees on average (Barrot and Sauvagnat, 2016).

Corporate bond issuers are headquartered in 226 different counties, with a majority of firms located in New York County. Some firms change their headquarters' location. For example, General Electric moved

\footnotetext{
${ }^{5}$ Data on HQs can also be obtained from Compustat. However, while it reports the address of a firm's current HQ location, it back-fills this information for previous years, and does not control for HQ relocations.

${ }^{6}$ https://sraf.nd.edu/data/augmented-10-x-header-data/
} 
from Fairfield, Connecticut to Boston, Massachusetts, in 2016. Among the firms in the sample, only 3\% (28 firms among 872) changed their headquarters' location between 2010-2018.

\subsection{Summary Statistics}

The final sample constitutes of 6,276 bonds issued by 872 distinct public companies, between 2010 and 2018. Summary statistics are reported in Table 2. Average yield spreads are $2.3 \%$, although they vary substantially, with a standard deviation of $2.8 \%$. On average, offering yields are $4.4 \%$ and equivalent treasury bond yields are equal to $2.1 \%$. Bonds included in the sample have ratings ranging from CCC- to AAA, and are rated $\mathrm{BBB}+$ on average. Bonds' average maturity is 11 years and investors receive a $4.4 \%$ fixed coupon. The average issuer has assets equal to $\$ 340$ billion, a return on assets of $4 \%$ annually, holds $37.1 \%$ of debts relative to total assets, and has a market-to-book ratio of 1.6. The companies included in the sample invest in material assets and hold on average $22 \%$ of their total assets in property, plants and equipment.

[Table 2 about here]

Average sales-weighted SLR for bond issuers is $0.006 \%$, ranging from 0 to $1.434 \%$. Weighing by number of employees or branches provides similar SLR exposure (i.e. 0.007\%). All measures capture important variation in geographic dispersion, with standard deviations ranging between $0.018 \%$ and $0.034 \%$. This feature is reflected in the number of counties in which an issuer has branches. On average, a firm is located in 251 different counties, ranging from 1 (Netflix Inc.) to 2,568 (for JP Morgan chase).

Correlations are reported in Table 4. SLR exposure measures are positively correlated with yield spreads, suggesting that higher climate change risk may lead to a higher cost of issuance. SLR is negatively correlated with credit ratings, indicating that higher exposure to climate change risk may reduce the credit quality of an issuer. The three SLR measures are highly positively correlated, ranging from 0.98 for sales and employee weighted measures, to 0.87 for sales and branch weighted measures. Higher geographic dispersion, proxied by the number of counties, is negatively correlated with yield spreads but positively correlated with credit quality. It is also negatively associated with sea level exposure, as can be expected, as geographic diversification allows attenuating climate risk exposure. Larger and more profitable firms are expected to have a lower cost of debt issues and better quality ratings, whereas increased leverage is associated with a higher cost of debt and lower ratings. Size is highly correlated with credit quality (0.61). 
[Table 4 about here]

\section{Climate Change Risk and Bond Characteristics at Issuance}

In this section, I first present the estimation procedure, followed by the main results. I then conduct robustness tests to verify the relation between SLR exposure and yield spreads holds.

\subsection{Regression Design}

To examine the impact of climate change risk on bond characteristics at issuance, I estimate the following ordinary least squares (OLS) regression focusing on corporate bonds issued from January 2010 to December 2018:

$$
\text { BondCharacteristics }=\alpha S L R+\beta^{\prime} \times X+\gamma+\epsilon
$$

with BondCharacteristics the yield spread or the credit rating of the bond at issuance; SLR is the branchlevel SLR exposure of the bond issuer, weighted either by the number of sales, employees or branches in a given county and year; $X$ is a vector of control variables including bond characteristics (amount issued, maturity, credit rating), firm characteristics (size, ROA, leverage, market-to-book, PPE), as well as countylevel economic conditions at the headquarters; $\gamma$ are year and industry fixed effects. Standard errors are clustered at the issuer level, as the residuals of the regressions could be correlated for repeated issues by a given firm.

To control for county-level local conditions at the firm headquarters, I include GdpPerCapita, where GDP in current dollars is obtained from the Bureau of Economic Analysis and population estimates are from the Census Bureau's Population Estimates Program. Unemployment rates ares provided by the U.S. Bureau of Labor Statistics. In addition, to control for unobserved aspects of the U.S. economy as well as common macroeconomic trends, I include both year fixed effects. Adding industry fixed effects allows identifying the impact of SLR on bond yields by comparing yields from different companies within a same industry.

Based on prior literature, I expect the parameter of interest, $\alpha$, to be positive for yield spreads, as investors require higher yields from companies exposed to higher SLR. However, I expect the coefficient to be negative when examining credit ratings, as higher exposure to SLR undermines the credit quality of the issuer. 


\subsection{Main Results}

Table 5 presents the results for the effects of SLR exposure on bond yield spreads. The first columns focuses on SLR exposure weighted by the relative sales amount in a given county, while the second and third columns report the effects of SLR exposure weighted by number of employees and branches. SLR exposure significantly impacts yield spreads, in all specifications, although significance is strongest when weighing by sales. Economic magnitudes are larger when weighting by employee and branch shares. Under specification (1), a one percentage point increase of SLR exposure at the branch-level is associated with a 1.7 percentage point increase in yield spreads, significant at the $1 \%$ level. In other words, a one standard deviation increase in a firm's sea level exposure $(0.034 \%)$ is expected to increase yield spreads by 0.04 percentage points, equivalent to a $2 \%$ increase of average yield spreads (2.3\%). Comparatively, a one notch increase in credit quality is expected to reduce the cost of issuance by 0.13 percentage point, or a one standard deviation increase in credit quality ( 3 notches) is related to a 0.4 reduction in yields. In line with other findings in the corporate bond literature, I find that issuance costs are lower for large amounts of bonds issued, for smaller maturities and better credit quality. The issuer's profitability is highly significant, indicating that investors require higher yields for less profitable firms. Both market-to-book and leverage are also highly significant, where higher leverage increases the cost of debt while higher growth opportunities reduce yield spreads. Finally, firms with higher shares of property, plant and equipment appear to have lower issuing costs.

[Table 5 about here]

Table 6 reports the effect of sea level rise exposure on credit ratings at issue. Overall, there is no compelling evidence that SLR exposure is accounted for by credit rating agencies at issuance. Focusing on specification (1), an additional percentage point of exposure to SLR predicts lower credit scores by 0.5 notches. The results are, however, not significant. Different weighting schemes provide similar results, although the sign becomes positive. In addition, improved credit quality is associated with larger firm size and longer maturities. Stronger profitability, growth expectations and lower leverage are significantly associated with better ratings, as expected.

The results in Table 6 imply that credit rating agencies do not yet consider physical climate risk when evaluating issuers, although they appear to capture regulatory risk (Seltzer et al., 2020). Credit ratings agencies' interest in climate risk is indeed relatively recent. Moody's acquisition of a climate data firm, signaling 
new scrutiny of climate risks, only dates back to July 2019 (Flavelle, 2019), following the publication of a new methodology to assess environmental, social and governance (ESG) risks published in September 2018 (Moody's, 2018). Overall, as pointed out by the Institute for Energy Economics and Financial analysis (IEEFA, 2019), credit rating agencies have been slow to act on climate change, which corroborates the results found in this study.

[Table 6 about here]

\subsection{Robustness Analysis}

A first concern with the sea level rise exposure measure is that unobserved coastal counties may bias the results associating branch-exposure to sea level rise exposure to yield spreads (Painter, 2020). In the baseline specification, all cities (and corresponding counties) for which Hallegatte et al. (2013) do not compute a loss estimate of flood risk are assumed to have a climate risk of zero. Therefore, firms located in coastal counties may be exposed to SLR, even though it is not quantified by this measure. Although this bias probably leads to an under-estimation of the effect of climate risk on bond yields, I address this concern by omitting unobserved coastal counties from the analysis. I identify coastal counties following the definition provided by the National Oceanic and Atmospheric Administration (NOAA) and replace zero values by missing observations, thereby excluding them for the weighted sea level computation. Table 7 columns (1)-(3) reports the results for this test, for the three weighted measures of SLR. Both the significance and magnitudes of the SLR effect on bond yields remain unchanged.

[Table 7 about here]

A second concern is that over-exposure to inland counties with no SLR may bias the estimated effect. I therefore verify whether omitting inland counties alters the regression results associating SLR exposure and yield spreads. In this setting, inland counties with zero SLR exposure are excluded from the weighted measure. The results of this test are reported in columns (4)-(6) of Table 7. The magnitude of the effect increases slightly and significance remains at the $1 \%$ level.

Another potential concern is that the small number of counties for which a measure of SLR is obtained is generating spurious correlation ${ }^{7}$. To address this issue, I conduct a placebo test which replaces exposed

\footnotetext{
${ }^{7}$ Only 37 counties have SLR estimates, as listed in Table 1.
} 
counties with inland neighboring counties, similarly to Painter (2020) and Jiang et al. (2019). Neighbor counties are likely to experience similar economic conditions to exposed counties albeit with no risk of sea level rise, given that they are inland. To identify neighbor non-coastal counties, I use county distance. ${ }^{8}$ and find the closest county that is not a coastal county. The results of this placebo test are presented in Table 8 . The coefficients for Neighbor SLR are no longer significant and are now negative. These results from this test provide some evidence that the sea level rise measure is correctly identifying climate risk, rather than picking up unobserved county-specific local traits.

Finally, I use inverse propensity weighting to alleviate concerns that observable factors are driving the results. I first separate firms into two groups: those with above median SLR exposure (treatment), and those with below levels of SLR exposure (control). I then estimate propensity scores using a logit model regressing the treatment group dummy on the following variables: firm size, ROA, leverage, market-to-book, PPE, vulnerable, credit rating, amount issued, bond maturity, HQ gdp per capita and unemployment rate, including year and industry fixed effects. I then run the baseline OLS regression after applying inverse propensity weighting and present the results in Table 9. The magnitudes of the coefficient are similar to those obtained when running the baseline regression, ranging from 1.3 to 2.8 , and all three are statistically significant at the $1 \%$ or $5 \%$ level. This test further alleviates concerns of confounding factors that may be driven by the choice of firms to locate their activities on coastal counties, by reducing differences between highly exposed firms and those less exposed to sea level rise.

\section{Corporate Heterogeneity and Pricing of Climate Change Risk}

In this section I examine the effect of spatial distribution, industry groups and investment horizon, on the SLR-spread relationship.

\subsection{Spatial Dispersion}

A challenge when considering corporate exposure to climate change risk, is accounting for spatial dispersion. While some firms are located in a unique county, some have branches located in more than 2,000 different locations. To verify whether highly dispersed firms are not driving the results, I first run the baseline regression by excluding issuers in the top decile of geographic dispersion, proxied by the number of counties in which a firm has branches. More specifically, I exclude issuers that are located in more that 802 counties.

\footnotetext{
${ }^{8}$ Using the county distance database https://data.nber.org/data/county-distance-database.html
} 
Results are reported in Table 10, Panel A. Results remain significant at the 1\% level for the sales weighted measure of SLR, and at the $10 \%$ level for employee and branch weighted measures. Economic magnitudes are similar.

To examine the impact of spatial distribution, I interact SLR exposure with the number of counties in which an issuer is located. Results are presented in Table 10, Panel B. Overall, the results indicate that the effect of sea level rise exposure on yield spread is reduced for spatially diversified firms. The coefficient estimates for the interacted variables are all negative, although not significant. Focusing on sales-weighted SLR exposure, the estimates indicate that a one percent point increase in SLR exposure leads to a 2.02 percentage point increase in yield spreads if the issuer is located in 1 county only. However, when located in 10 different counties, the effect is limited to a 0.85 percentage point increase in yield spreads. The results suggest that by being geographically dispersed, issuers can diversify their climate risk exposure.

\subsection{Industry Heterogeneity}

Another specificity of corporate exposure to climate change risk is that it depends on the business type of each firm. Companies located in areas with SLR will be less exposed if their activities have lower chances of being disrupted by floods. For example, Belasen and Polachek (2008) find that the construction and service sectors are positively impacted following a hurricane, while the manufacturing, trade, transportation, and utility, as well as the finance, investment, and real estate industries are negatively affected. In particular, firms with substantial physical or tangible long-term assets (i.e. property, plant, and equipment including buildings, machinery, land, office equipment, furniture, and vehicles) are at higher risk of being impacted by floods and extreme weather conditions. Therefore, baseline regressions include PPE as a control variable.

Huang et al. (2018) identifies industries which are vulnerable to extreme weather conditions in two ways. First, extreme weather conditions can affect corporate profitability by damaging assets (Reisch, 2005), especially for industries with heavy non-deployed and long-lived capital assets which include energy, healthcare and utilities (SASB, 2016; Wilbanks et al., 2007; McCarthy et al., 2001). Second, extreme weather events can disrupt business operations and result in operating losses, especially for firms dependent on moderate weather conditions which heavily rely on infrastructure, such as agriculture, food manufacturing, business services and transportation.

In this section, I examine whether exposure to SLR affects bond yields differently depending on 
whether the issuer operates in a vulnerable industry or not. Following Huang et al. (2018), I consider agriculture, energy (mining and oil extraction), food products, healthcare, communications, business services, and transportation, as industries vulnerable to climate change risk. I create a dummy variable equal to 1 if an issuer is in one of these industries, identified using the Fama-French 48 industry classification, and 0 otherwise. ${ }^{9}$ I first examine whether the effect of SLR on yield spreads differ for vulnerable industries, relative to non-vulnerable industries. As can be seen in Table 11, Panel A, the effect of SLR exposure on the cost of debt issuance seems to be driven by issuers operating in vulnerable industries. Although the estimates for the non-vulnerable industries are positive, significance disappears. Panel B provides an additional breakdown by industry group. The two main sectors driving the results are Communication (e.g. ATT, Verizon, or Time Warner) and Energy (e.g. Phillips 66, Chevron, or Exxon Mobil). These industry-specific result provide additional evidence supporting the link between SLR exposure and the cost of corporate bond issuance.

[Table 11 about here]

\subsection{Investor Horizons}

An important challenge for investors when considering climate change risk is the uncertainty of the time horizon in which these risks are likely to materialize (Barnett et al., 2020). According to institutional investors surveyed by Krueger et al. (2020), fewer than $10 \%$ believe that climate risks will materialize only in 10 years or more. Among the 401 respondents, $34 \%$ believe that physical climate risks has already materialized today. However, Painter (2020), when examining the period ranging from January 2004 and March 2017, finds that investors price climate change risk in long-term municipal bonds (i.e. with maturities greater than 25 years).

To examine the role of investment horizon for bonds issued between January 2010 and December 2018, I separate my sample of bonds into four categories based on bond maturities, and examine the effect of sea level rise exposure on yield spreads. The results reported in Table 12 indicate that excess cost resulting from SLR exposure is driven by bonds with maturities ranging from 5 to 10 years. Contrary to Painter (2020), I do not find a significant effect for bonds with maturities above 10 years. The discrepancy of results may however stem from a differing sample period, as my focus is on bonds issued between 2010 and 2018. In

\footnotetext{
${ }^{9}$ Vulnerable Industries is an indicator variable that equals one for Agriculture (Fama-French Industry Code 1), Business Services (Code 34), Communication (Code 32), Energy [Mines (Code 28), Coal (Code 29), and Oil (Code 30)], Food Products (Code 2), Health Care (Code 11), and Transportation (Code 40), and zero otherwise.
} 
addition, these results seem in line with the survey responses collected by (Krueger et al., 2020).

[Table 12 about here]

Overall, the evidence relayed in the previous sections suggests that firms located in counties with sea level rise exposure pay a premium when issuing bonds with maturities ranging from 5-10 years. This effect is particularly important for vulnerable industries in the Communication or Energy sector. Spatial diversification allows to mitigate this effect, which is stronger for firms present in less counties.

\section{Conclusion}

This study provides empirical evidence on the pricing of physical climate risk in U.S. corporate bonds. I find that investors require a premium for bonds issued by firms exposed to sea level rise, especially those with activities identified as vulnerable to floods and extreme weather events (e.g. Communication and Energy sectors), less geographically diversified across the U.S., and which issue bonds with maturities ranging from 5 to 10 years. In addition, I find no evidence that sea level rise exposure is accounted for in credit ratings at issuance, supporting anecdotal evidence that credit rating agencies are not adequately taking into account physical climate risk.

Although prior research has shown the importance of firms' regulatory risk for investors, this paper is the first to examine how physical climate change risk impacts corporate fixed income assets and their ratings at issuance. Importantly, by capturing sea level rise exposure at the branch level, I obtain a fuller view of corporate SLR exposure than by focusing solely on firms' HQ location.

The evidence found in this study has important implications for firms considering where to locate branches in the U.S., in particular those vulnerable to floods and extreme weather events. Reducing exposure to sea level rise appears to be a way to mitigate the cost of issuing debt, as well as spatially diversifying locations, although evidence is not as strong. In addition, this study finds support for an inadequate account of climate change risk in at-issue credit ratings, a warning for policymakers concerned with financial stability and the risk of a future climate credit crunch. 


\section{References}

Addoum, J. M., D. T. Ng, and A. Ortiz-Bobea 2019. Temperature shocks and earning news. Review of Financial Studies.

Amiraslani, H., K. V. Lins, H. Servaes, and A. Tamayo 2017. A matter of trust? the bond market benefits of corporate social capital during the financial crisis.

Baker S. R., S. T. Sun, and C. Yannelis 2020. Corporate taxes and retail prices. Technical report, National Bureau of Economic Research.

Baldauf, M., L. Garlappi, and C. Yannelis 2020. Does climate change affect real estate prices? only if you believe in it. The Review of Financial Studies 33(3) 1256-1295.

Bansal, R., D. Kiku, and M. Ochoa 2019. Climate change risk. preprint. URL https://www. frbsf. org/economic-research/events/2019/november/economics-of-climate-change/files/P.

Barnett, M., W. Brock, and L. P. Hansen 2020. Pricing uncertainty induced by climate change. The Review of Financial Studies 33(3), 1024-1066.

Barrot, J.-N. and J. Sauvagnat 2016. Input specificity and the propagation of idiosyncratic shocks in production networks. The Quarterly Journal of Economics 131(3), 1543-1592.

Belasen, A. R. and S. W. Polachek 2008. How hurricanes affect wages and employment in local labor markets. American Economic Review 98(2), 49-53.

Bernstein, A., M. T. Gustafson, and R. Lewis 2019. Disaster on the horizon: The price effect of sea level rise. Journal of Financial Economics 134(2), 253-272.

Bertolotti, A., D. Basu, K. Akallal, and B. Deese 2019. Climate risk in the us electric utility sector: A case study. Available at SSRN 3347746.

Bhojraj, S. and P. Sengupta 2003. Effect of corporate governance on bond ratings and yields: The role of institutional investors and outside directors. The journal of Business 76(3), 455-475.

Brock, W. A. and L. P. Hansen 2018. Wrestling with uncertainty in climate economic models. University of Chicago, Becker Friedman Institute for Economics Working Paper (2019-71).

Capasso, G., G. Gianfrate, and M. Spinelli 2020. Climate change and credit risk. Journal of Cleaner Production, 121634.

Carney, M. 2015. Breaking the tragedy of the horizon-climate change and financial stability. Speech given at Lloyd's of London 29, 220-230.

CIEL 2015, May. Climate risk. Technical report, The Center for International Environmental Law. https : //www.ciel.org/wp-content/uploads/2015/10/ciel-rpt-credits-10.15-webv2smaller.pdf.

Duan, T. and F. W. Li 2019. Worrying about climate change: Evidence from mortgage lending. Available at SSRN 3449696.

Flammer, C. 2015. Does corporate social responsibility lead to superior financial performance? a regression discontinuity approach. Management Science 61(11) 2549-2568.

Flammer, C., M. W. Toffel, and K. Viswanathan 2019. Shareholder activism and firms' voluntary disclosure of climate change risks. Available at SSRN.

Flannery, M. J., Ö. Öztekin, et al. 2012. Leverage expectations and bond credit spreads. Journal of Financial and Quantitative Analysis 47(4), 689-714. 
Flavelle, C. 2019. Moody's buys climate data firm, signaling new scrutiny of climate risks. New York Times 24.

Gold, R. 2019, January. Pg\&e: The first climate-change bankruptcy, probably not the last. Wall Street Journal.

Goldsmith-Pinkham, P., M. T. Gustafson, R. C. Lewis, and M. Schwert 2020. Sea level rise exposure and municipal bond yields.

Griffin, P., D. Lont, and M. Lubberink 2019. Extreme high surface temperature events and equity-related physical climate risk. Weather and Climate Extremes 26, 100220.

Hallegatte, S., C. Green, R. J. Nicholls, and J. Corfee-Morlot 2013. Future flood losses in major coastal cities. Nature climate change 3(9), 802-806.

Hansen, J. M., T. Aagaard, and A. Kuijpers 2015. Sea-level forcing by synchronization of 56-and 74-year oscillations with the moon's nodal tide on the northwest european shelf (eastern north sea to central baltic sea). Journal of Coastal Research 31(5), 1041-1056.

Hong, H., F. W. Li, and J. Xu 2019. Climate risks and market efficiency. Journal of Econometrics 208(1), $265-281$.

Huang, H. H., J. Kerstein, and C. Wang 2018. The impact of climate risk on firm performance and financing choices: An international comparison. Journal of International Business Studies 49(5), 633-656.

Hugon, A. and K. Law 2019. Impact of climate change on firm earnings: evidence from temperature anomalies. Available at SSRN 3271386.

IEEFA 2019, August. Climate change becomes an issue for ratings agencies.

Indaco, A., F. Ortega, and S. Taspinar 2019. Hurricanes, flood risk and the economic adaptation of businesses.

IPCC 2018. Global warming of 1.5c. Technical report, An IPCC Special Report on the impacts of global warming. https://www.ipcc.ch/site/assets/uploads/sites/2/2019/06/SR15_Full_Report_High_Res.pdf.

Jiang, F., C. W. Li, and Y. Qian 2019. Can firms run away from climate-change risk? evidence from the pricing of bank loans. Evidence from the Pricing of Bank Loans (April 15 2019).

Jiraporn P., N. Jiraporn, A. Boeprasert, and K. Chang 2014. Does corporate social responsibility (csr) improve credit ratings? evidence from geographic identification. Financial Management 43(3) 505-531.

Kocornik-Mina, A., T. K. McDermott, G. Michaels, and F. Rauch 2015. Flooded cities.

Krasting, J. P., J. P. Dunne, R. J. Stouffer, and R. W. Hallberg 2016. Enhanced atlantic sea-level rise relative to the pacific under high carbon emission rates. Nature Geoscience 9(3), 210-214.

Krueger, P., Z. Sautner, and L. T. Starks 2020. The importance of climate risks for institutional investors. The Review of Financial Studies 33(3), 1067-1111.

Kruttli, M., B. Roth Tran, and S. W. Watugala 2019. Pricing poseidon: extreme weather uncertainty and firm return dynamics.

Macwilliams, J. J., S. La Monaca, and J. Kobus 2019. Pg\&e: Market and policy perspectives on the first climate change bankruptcy.

Matsumura, E. M., R. Prakash, and S. C. Vera-Munoz 2017. To disclose or not to disclose climate-change risk in form 10-k: Does materiality lie in the eyes of the beholder? Available at SSRN 2986290.

McCarthy J. J., O. F. Canziani, N. A. Leary, D. J. Dokken, K. S. White, et al. 2001. Climate change 2001: impacts, adaptation, and vulnerability: contribution of Working Group II to the third assessment report of 
the Intergovernmental Panel on Climate Change, Volume 2. Cambridge University Press.

Moody's 2017. Us municipal bond defaults and recoveries,1970-2016. Moody's Investors Service.

Moody's 2018, August. General principles for assessing environmental, social and governance risks.

Murfin, J. and M. Spiegel 2020. Is the risk of sea level rise capitalized in residential real estate? The Review of Financial Studies 33(3) 1217-1255.

Nauman, B. 2020, January. Municipal bond issuers face steeper borrowing costs from climate change. Financial Times.

Painter, M. 2020. An inconvenient cost: The effects of climate change on municipal bonds. Journal of Financial Economics 135(2), 468-482.

Pan, Y., E. Pikulina, S. Siegel, and T. Y. Wang 2019. Equity market reaction to pay dispersion: Evidence from ceo-worker pay ratio disclosure. Available at SSRN.

Pankratz, N., R. Bauer, and J. Derwall 2019. Climate change, firm performance, and investor surprises. Firm Performance, and Investor Surprises (May 21, 2019).

Reisch, M. 2005. Katrina's impact.

SASB 2016. Climate risk. Technical report, Technical Bulletin on Climate Risk. https://www.eenews.net/ assets/2016/10/20/document_cw_01.pdf.

Seltzer, L., L. Starks, and Q. Zhu 2020. Climate regulatory risks and corporate bonds. Available at SSRN 3563271 .

Sweet, W. V., R. E. Kopp, C. P. Weaver, J. Obeysekera, R. M. Horton, E. R. Thieler, and C. Zervas 2017. Global and regional sea level rise scenarios for the United States.

Wilbanks, T. J., P. R. Lankao, M. Bao, F. Berkhout, S. Cairncross, J.-P. Ceron, M. Kapshe, R. Muir-Wood, and R. Zapata-Marti 2007. Industry, settlement and society. In Climate Change 2007: Impacts, Adaptation and Vulnerability, Contribution of Working Group II to the Fourth Assessment Report of the Intergovernmental Panel on Climate Change, pp. 357-390. Cambridge University Press.

Yang, H. 2018. Regional economic growth and firm performance. 
Figure 1: Counties Exposed to Sea Level Rise

This Figure presents counties exposed to sea level rise, as computed by (Hallegatte et al., 2013). Expected mean annual losses as a percentage of a city's GDP are obtained assuming a $40 \mathrm{~cm}$ rise in the sea level as of 2050 and that cities attempt to adapt to this rise. Cities are then mapped to counties following (Painter, 2020). All counties for which there is no measure computed by (Hallegatte et al., 2013) are assigned a SLR of zero.

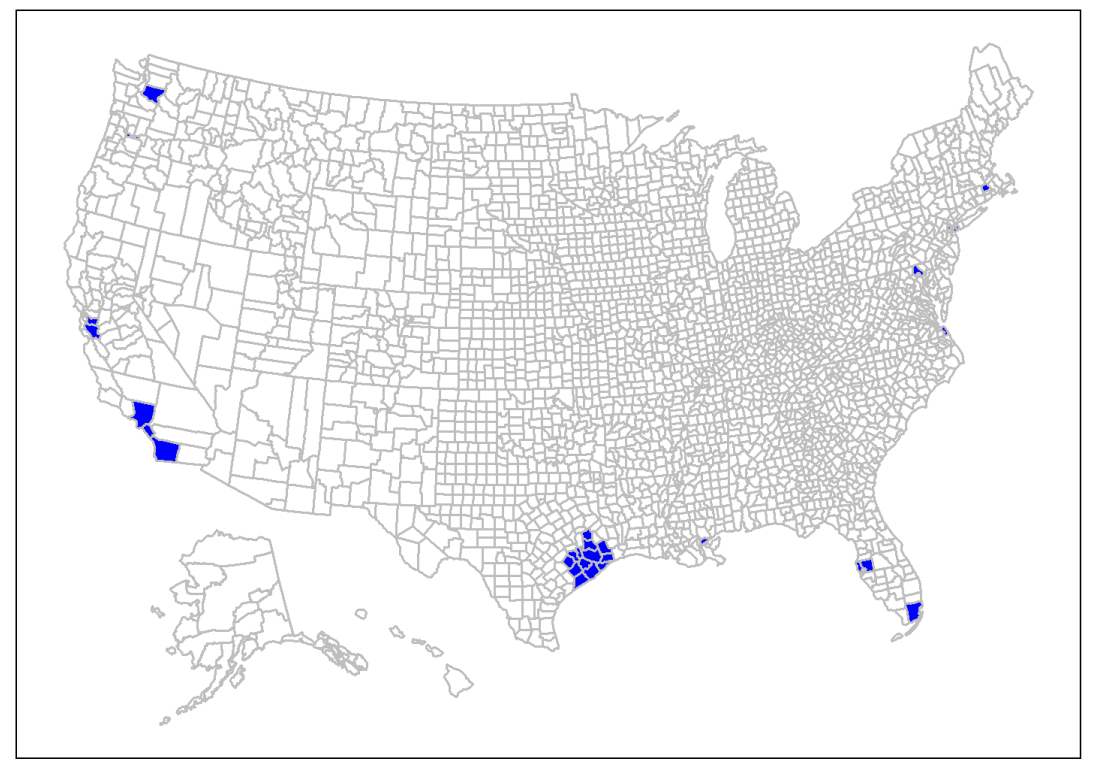


Table 1: Variables and Data Sources

\begin{tabular}{|c|c|c|}
\hline Variable & Definition & Data Source \\
\hline \multicolumn{3}{|c|}{ A: At-issue Bond Level variables } \\
\hline YieldSpread $_{i, t}$ & $\begin{array}{l}\text { Bond i's yield spread at issue in year-month t. It is equal to the difference between bond i's } \\
\text { offering yield and the yield of a treasury bond with similar maturities. It is expressed in } \\
\text { percentage. }\end{array}$ & FISD Mergent \\
\hline CreditRating $_{i, t}$ & $\begin{array}{l}\text { The credit rating of bond i issued in year-month t. Credit ratings are transformed to numerical } \\
\text { values such that the lowest rating is equal to } 1 \text { (D), and the highest is equal to } 22 \text { (equivalent to } \\
\text { AAA). Credit ratings are either provided by S\&P, Moody's or Fitch, in this order of availability. }\end{array}$ & FISD Mergent \\
\hline OfferingYield ${ }_{i, t}$ & Bond i's offering yield at issue in year-month t, expressed in percentage. & FISD Mergent \\
\hline OfferingPrice $_{i, t}$ & Bond i's offering price at issue in year-month t, expressed in percentage. & FISD Mergent \\
\hline Maturity $_{i, t}$ & Bond i's maturity at issue in year-month t, expressed in years. & FISD Mergent \\
\hline Amount $_{i, t}$ & Bond i's amount issued in year-month $t$, expressed in log of the dollar amount. & FISD Mergent \\
\hline \multicolumn{3}{|c|}{ B: Issuer Level Variables } \\
\hline Size $_{j, t}$ & The size of issuer $\mathrm{j}$ in year $\mathrm{t}$, expressed in log of the dollar amount of total assets (at). & Compustat \\
\hline $\mathrm{ROA}_{j, t}$ & $\begin{array}{l}\text { The return on assets of issuer } \mathrm{j} \text { in year } \mathrm{t} \text {. It is computed as the ratio of net income (ni) on total } \\
\text { assets (at). }\end{array}$ & Compustat \\
\hline Leverage $_{j, t}$ & $\begin{array}{l}\text { The leverage of issuer } \mathrm{j} \text { in year } \mathrm{t} \text {, computed as the sum of long term debt (dltt) and current debt } \\
\text { (dlc) divided by total assets (at). }\end{array}$ & Compustat \\
\hline $\mathrm{MtB}_{j, t}$ & $\begin{array}{l}\text { The market-to-book value of issuer } \mathrm{j} \text { in year t. It is obtained as follows: } \\
\left(a t-s e q+c s h o * p r c c_{f}\right) / a t\end{array}$ & Compustat \\
\hline $\mathrm{PPE}_{j, t}$ & The ratio of property plant and equipment (ppent) to total assets (at), of issuer $\mathrm{j}$ in year $\mathrm{t}$. & Compustat \\
\hline SLR_Sales $_{j, t}$ & $\begin{array}{l}\text { The weighted-average sea level rise exposure of issuer } \mathrm{j} \text { in year } \mathrm{t} \text {, based on sales weights and } \\
\text { issuer's geographic presence in the U.S. }\end{array}$ & $\begin{array}{l}\text { Infogroup and } \\
\text { (Hallegatte et al., } \\
\text { 2013) }\end{array}$ \\
\hline SLR_Employ $_{j, t}$ & $\begin{array}{l}\text { The weighted-average sea level rise exposure of issuer } \mathrm{j} \text { in year } \mathrm{t} \text {, based on the fraction of } \\
\text { employee and issuer's geographic presence in the U.S. }\end{array}$ & $\begin{array}{l}\text { Infogroup and } \\
\text { (Hallegatte et al., } \\
\text { 2013) }\end{array}$ \\
\hline SLR_Branch $_{j, t}$ & $\begin{array}{l}\text { The weighted-average sea level rise exposure of issuer } \mathrm{j} \text { in year } \mathrm{t} \text {, based on relative number of } \\
\text { branches and issuer's geographic presence in the U.S. }\end{array}$ & $\begin{array}{l}\text { Infogroup and } \\
\text { (Hallegatte et al., } \\
\text { 2013) }\end{array}$ \\
\hline NbrCounties $_{j, t}$ & The number of U.S. counties in which issuer $\mathrm{j}$ is located in year $\mathrm{t}$. & Infogroup \\
\hline \multicolumn{3}{|c|}{ D: County Level Variables } \\
\hline $\mathrm{SLR}_{c}$ & $\begin{array}{l}\text { The expected mean annual loss computed assuming a } 40 \mathrm{~cm} \text { rise in sea level, in percentage of a } \\
\text { city's GDP. Cities are mapped to counties, and counties with no expected losses or situated inland } \\
\text { are assigned } 0 .\end{array}$ & $\begin{array}{l}\text { (Hallegatte et al., } \\
\text { 2013) }\end{array}$ \\
\hline Unemployment $_{c, t}$ & The unemployment rate of county $\mathrm{c}$ in year $\mathrm{t}$, expressed in percentage. & $\begin{array}{l}\text { U.S. Bureau of } \\
\text { Labor Statistics }\end{array}$ \\
\hline GdpPerCapita $_{c, t}$ & Current-dollar GDP in county $\mathrm{c}$ and year $\mathrm{t}$ divided by the Population of county $\mathrm{c}$ in year $\mathrm{t}$. & $\begin{array}{l}\text { Bureau of Eco- } \\
\text { nomic Analysis } \\
\text { and USDA }\end{array}$ \\
\hline
\end{tabular}


Table 2: Summary Statistics

This table presents the descriptive statistics for the sample of U.S. corporate bonds issued between 2010 and 2018. All bond characteristics are obtained from FISD Mergent. Yield spreads at issue are obtained by taking the difference between the bond's offering yield and a treasury bond with matching maturity. Credit ratings are, by order of priority, obtained from SP, Moody's or Fitch, and transformed to numerical values, ranging from 1 (D) to 22 (AAA). The offering price is the price at issue of the bond, maturity is expressed in number of years, and the amount at issue is $\log$ transformed. Issuer characteristics are obtained from Compustat on an annual basis. Size is the log of total assets, ROA the ratio between net income and total assets, leverage the ratio between debt (long term and current) and total assets, MtB the market-to-book ratio, and PPE the amount of property, plants and equipment relative to total assets. Sea level rise (SLR) is the exposure to climate change risk at branch locations. It is weighted by the fraction of sales (SLR_Sales), employees (SLR_Employ) and number of branches (SLR_Branch) on each issuer. NbrCounties is the number of counties in which an issuer has branches. GDP per Capital and Unemployment control for economic conditions at headquarters.

\begin{tabular}{lccccccc}
\hline Statistic & $\mathrm{N}$ & Mean & St. Dev. & Min & Pctl(25) & Pctl(75) & Max \\
\hline YieldSpread (\%) & 6,276 & 2.303 & 2.772 & 0.004 & 1.002 & 2.532 & 64.136 \\
OfferingYield (\%) & 6,276 & 4.419 & 2.650 & 0.511 & 3.050 & 5.001 & 64.250 \\
TreasuryYield (\%) & 6,276 & 2.116 & 0.860 & 0.078 & 1.584 & 2.761 & 4.690 \\
CreditRating & 6,276 & 14.611 & 3.173 & 4 & 13 & 17 & 22 \\
OfferingPrice & 6,276 & 99.783 & 1.469 & 25.000 & 99.732 & 100.000 & 109.750 \\
Maturity & 6,276 & 11.120 & 9.068 & 0.178 & 5.044 & 10.203 & 100.079 \\
Coupon (\%) & 6,276 & 4.393 & 2.648 & 0.450 & 3.000 & 5.000 & 64.250 \\
Amount & 6,276 & 11.925 & 2.478 & 2.890 & 10.145 & 13.528 & 16.524 \\
Size & 6,276 & 11.010 & 2.094 & 4.270 & 9.352 & 12.587 & 14.761 \\
ROA & 6,276 & 0.040 & 0.061 & -1.236 & 0.008 & 0.067 & 0.443 \\
Leverage & 6,276 & 0.371 & 0.178 & 0.000 & 0.245 & 0.492 & 1.850 \\
MtB & 6,276 & 1.605 & 0.878 & 0.510 & 1.005 & 1.857 & 8.607 \\
PPE & 6,276 & 0.219 & 0.259 & 0.000 & 0.012 & 0.343 & 0.968 \\
SLR_Sales (\%) & 6,276 & 0.006 & 0.034 & 0.000 & 0.001 & 0.005 & 1.434 \\
SLR_Employ (\%) & 6,276 & 0.007 & 0.033 & 0.000 & 0.001 & 0.005 & 1.422 \\
SLR_Branch (\%) & 6,276 & 0.007 & 0.018 & 0.000 & 0.001 & 0.007 & 0.740 \\
NbrCounties & 6,276 & 250.860 & 398.516 & 1 & 27 & 237 & 2,568 \\
GdpPerCapita & 6,276 & 148.620 & 125.203 & 20.036 & 63.714 & 300.442 & 437.142 \\
Unemployment (\%) & 6,276 & 6.259 & 2.140 & 2.000 & 4.500 & 7.800 & 15.500 \\
\hline
\end{tabular}


Table 3: Counties With Sea Level Rise Exposure

This table presents cities and counties ranked by sea level rise (SLR) exposure. The SLR measure estimates expected mean annual losses as a percentage of a city's GDP, assuming a $40 \mathrm{~cm}$ rise in the sea level as of 2050 and that cities attempt to adapt to this rise, as computed by (Hallegatte et al., 2013). All counties not included in this table are assigned a SLR of zero.

\begin{tabular}{|c|c|c|c|}
\hline City & State & Counties & Sea Level Rise Exposure \\
\hline New Orleans & LA & Orleans & $1.479 \%$ \\
\hline Miami & FL & Dade & $0.420 \%$ \\
\hline Tampa, St. Petersburg & FL & Hillsborough, Pinellas & $0.324 \%$ \\
\hline Virginia Beach & VA & Virginia Beach & $0.173 \%$ \\
\hline Boston & MA & Suffolk & $0.149 \%$ \\
\hline Baltimore & MD & Baltimore & $0.104 \%$ \\
\hline LA, Long Beach, Santa Ana & CA & Los Angeles, Orange & $0.097 \%$ \\
\hline New York, Newark & NY & Bronx, Kings, NY, Queens, Richmond, Essex & $0.089 \%$ \\
\hline Providence & RI & Providence & $0.083 \%$ \\
\hline Philadelphia & PA & Philadelphia & $0.044 \%$ \\
\hline San Francisco, Oakland & $\mathrm{CA}$ & San Francisco, Alameda & $0.042 \%$ \\
\hline Houston & $\mathrm{TX}$ & $\begin{array}{l}\text { Walker, Montgomery, Liberty, Waller, Austin, } \\
\text { Harris, Chambers, Colorado, Wharton, Fort } \\
\text { Bend,Galveston, Brazoria, Matagorda }\end{array}$ & $0.038 \%$ \\
\hline Seattle & WA & King & $0.023 \%$ \\
\hline Washington D.C. & $\mathrm{DC}$ & Washington & $0.016 \%$ \\
\hline San Diego & $\mathrm{CA}$ & San Diego & $0.004 \%$ \\
\hline Portland & OR & Multnomah & $0.002 \%$ \\
\hline San Jose & $\mathrm{CA}$ & Santa Clara & $0.001 \%$ \\
\hline
\end{tabular}


Table 4: Correlation

This table reports the pairwise correlation of the main variables included in the analysis. Yield spreads at issue are obtained by taking the difference between a bond's offering yield and the yield of a matched treasury bond with similar maturity. Credit ratings are, by other of priority, obtained from SP, Moody's or Fitch, and transformed to numerical values, ranging from 1 (D) from the lowest rating to 22 (AAA). Bond maturity is expressed in number of years, and the amount at issue is log transformed. Size is the log of total assets, ROA the ratio between net income and total assets, leverage the ratio between debt (long term and current) and total assets, MtB the market-to-book ratio, and PPE the amount of property, plants and equipment relative to total assets. Sea level rise (SLR) is the exposure to climate change risk at branch locations. It is weighted by the fraction of sales (SLR_Sales), employees (SLR_Employ) and number of branches (SLR_Branch). NbrCounties is the number of counties in which an issuer has branches. Statistical significance at the $0.01 \%, 0.1 \%, 1 \%$, $5 \%$ levels is indicated by $* * * *, * * *, * *$, and * respectively.

\begin{tabular}{|c|c|c|c|c|c|c|c|c|c|c|c|c|}
\hline & YieldSpread & CreditRating & Maturity & Amount & Size & ROA & Leverage & MtB & PPE & SLR_Sales & SLR_Employ & SLR_Branch \\
\hline \multicolumn{13}{|l|}{ YieldSpread } \\
\hline CreditRating & $-0.21 * * * * *$ & & & & & & & & & & & \\
\hline Maturity & $-0.17 * * * *$ & $0.10^{* * * *}$ & & & & & & & & & & \\
\hline Amount & $-0.25 * * * *$ & $-0.10 * * * *$ & $0.12 * * * *$ & & & & & & & & & \\
\hline Size & -0.02 & $0.61 * * * *$ & $0.03 *$ & $-0.49 * * * *$ & & & & & & & & \\
\hline ROA & $-0.23 * * * *$ & $0.24 * * * *$ & $0.12 * * * *$ & $0.25 * * * *$ & $-0.19 * * * *$ & & & & & & & \\
\hline Leverage & $0.08 * * * *$ & $-0.31 * * * *$ & $-0.03 *$ & $-0.23 * * * *$ & $-0.04 * *$ & $-0.11 * * * *$ & & & & & & \\
\hline $\mathrm{MtB}$ & -0.20 ***** & $0.15^{* * * *}$ & $0.08 * * * *$ & $0.34 * * * *$ & $-0.36 * * * *$ & $0.59 * * * *$ & $0.04 * *$ & & & & & \\
\hline PPE & 0.00 & $-0.28 * * * *$ & $0.10 * * * *$ & $0.33 * * * *$ & $-0.42 * * * *$ & 0.01 & $0.09 * * * *$ & $0.10 * * * *$ & & & & \\
\hline SLR_Sales & $0.03 * *$ & $-0.06 * * * *$ & -0.02 & $0.03^{*}$ & $-0.08 * * * *$ & $0.05^{* * * *}$ & 0.02 & 0.02 & $0.04 * * *$ & & & \\
\hline SLR_Employ & $0.08 * * * *$ & $-0.05 * * *$ & $-0.04 * *$ & 0.00 & $-0.06^{* * * *}$ & $0.04 * *$ & 0.00 & 0.00 & 0.02 & $0.98 * * * *$ & & \\
\hline SLR_Branch & $0.07 * * * *$ & $-0.04 * *$ & $-0.05 * * * *$ & -0.01 & $-0.06 * * * *$ & 0.02 & 0.01 & 0.00 & -0.02 & $0.87 * * * *$ & $0.89 * * * *$ & \\
\hline NbrCounties & $-0.15^{* * * * *}$ & $0.21 * * * *$ & $0.10 * * * *$ & $0.11 * * * *$ & $0.20 * * * *$ & $0.12 * * * *$ & $-0.04 * *$ & $0.10 * * * *$ & $0.10^{* * * * *}$ & $-0.07 * * * *$ & $-0.08 * * * *$ & $-0.16 * * * *$ \\
\hline
\end{tabular}


Table 5: Climate Change Risk and Yield Spreads at Issue

This table presents the results of the ordinary least squares regressions of equation (2), where the bond characteristic of interest is yield spreads. Sea level rise (SLR) is the exposure to climate change risk at branch locations. It is weighted by the fraction of sales (SLR_Sales), employees (SLR_Employ) and number of branches (SLR_Branch). Industry and Year fixed effects are included in all specifications. Standard errors are clustered by issuer.

\begin{tabular}{|c|c|c|c|}
\hline \multirow{2}{*}{$\begin{array}{l}\text { Dependent Variable: } \\
\text { Model: }\end{array}$} & \multicolumn{3}{|c|}{ YieldSpread } \\
\hline & (1) & (2) & (3) \\
\hline \\
\hline SLR_Sales & $\begin{array}{c}1.7478^{* * *} \\
(0.6595)\end{array}$ & & \\
\hline SLR_Employ & & $\begin{array}{l}3.3780^{*} \\
(1.9914)\end{array}$ & \\
\hline SLR_Branch & & & $\begin{array}{l}5.3231^{*} \\
(3.0191)\end{array}$ \\
\hline Maturity & $\begin{array}{l}-0.0060 \\
(0.0132)\end{array}$ & $\begin{array}{l}-0.0058 \\
(0.0131)\end{array}$ & $\begin{array}{l}-0.0059 \\
(0.0132)\end{array}$ \\
\hline Amount & $\begin{array}{l}-0.3669 \\
(0.2392)\end{array}$ & $\begin{array}{l}-0.3660 \\
(0.2385)\end{array}$ & $\begin{array}{l}-0.3670 \\
(0.2387)\end{array}$ \\
\hline Size & $\begin{array}{l}-0.2313 \\
(0.1454)\end{array}$ & $\begin{array}{l}-0.2270 \\
(0.1442)\end{array}$ & $\begin{array}{l}-0.2236 \\
(0.1425)\end{array}$ \\
\hline ROA & $\begin{array}{c}-3.1361^{* * *} \\
(0.9040)\end{array}$ & $\begin{array}{c}-3.2300^{* * *} \\
(0.9280)\end{array}$ & $\begin{array}{c}-3.1616^{* * *} \\
(0.9105)\end{array}$ \\
\hline Leverage & $\begin{array}{c}2.5925^{* * *} \\
(0.6559)\end{array}$ & $\begin{array}{l}2.5914^{* * *} \\
(0.6535)\end{array}$ & $\begin{array}{c}2.5797^{* * *} \\
(0.6496)\end{array}$ \\
\hline CreditRating & $\begin{array}{l}-0.1334 \\
(0.0949)\end{array}$ & $\begin{array}{l}-0.1338 \\
(0.0945)\end{array}$ & $\begin{array}{l}-0.1352 \\
(0.0940)\end{array}$ \\
\hline $\mathrm{MtB}$ & $\begin{array}{c}-0.2729^{* * *} \\
(0.0864)\end{array}$ & $\begin{array}{c}-0.2705^{* * *} \\
(0.0856)\end{array}$ & $\begin{array}{c}-0.2683^{* * *} \\
(0.0853)\end{array}$ \\
\hline PPE & $\begin{array}{l}-0.6004 \\
(0.4234)\end{array}$ & $\begin{array}{l}-0.6138 \\
(0.4313)\end{array}$ & $\begin{array}{l}-0.6257 \\
(0.4393)\end{array}$ \\
\hline GdpPerCapita & $\begin{array}{l}0.0037^{*} \\
(0.0021)\end{array}$ & $\begin{array}{l}0.0036^{*} \\
(0.0021)\end{array}$ & $\begin{array}{l}0.0036^{*} \\
(0.0021)\end{array}$ \\
\hline Unemployment & $\begin{array}{c}-0.2360^{* *} \\
(0.1088)\end{array}$ & $\begin{array}{c}-0.2364^{* *} \\
(0.1086)\end{array}$ & $\begin{array}{c}-0.2362^{* *} \\
(0.1087)\end{array}$ \\
\hline Fixed-Effects & & & \\
\hline Year & Yes & Yes & Yes \\
\hline Industry & Yes & Yes & Yes \\
\hline Fit statistics & & & \\
\hline Observations & 6,276 & 6,276 & 6,276 \\
\hline $\mathrm{R}^{2}$ & 0.45209 & 0.45323 & 0.45276 \\
\hline Within $\mathrm{R}^{2}$ & 0.22286 & 0.22447 & 0.22381 \\
\hline
\end{tabular}


Table 6: Climate Change Risk and Credit Ratings at Issue

This table presents the results of the ordinary least squares regressions of equation (2), where the bond characteristic of interest is credit ratings. Sea level rise (SLR) is the exposure to climate change risk at branch locations. It is weighted by the fraction of sales (SLR_Sales), employees (SLR_Employ) and number of branches (SLR_Branch). Industry and Year fixed effects are included in all specifications. Standard errors are clustered by issuer.

\begin{tabular}{|c|c|c|c|}
\hline \multirow{2}{*}{$\begin{array}{l}\text { Dependent Variable: } \\
\text { Model: }\end{array}$} & \multicolumn{3}{|c|}{ CreditRating } \\
\hline & (1) & (2) & (3) \\
\hline \multicolumn{4}{|l|}{ Variables } \\
\hline SLR_Sales & $\begin{array}{l}-0.4693 \\
(1.1515)\end{array}$ & & \\
\hline SLR_Employ & & $\begin{array}{c}0.0498 \\
(1.5313)\end{array}$ & \\
\hline SLR_Branch & & & $\begin{array}{c}2.2841 \\
(4.0409)\end{array}$ \\
\hline Maturity & $\begin{array}{c}0.0047 \\
(0.0044)\end{array}$ & $\begin{array}{c}0.0047 \\
(0.0044)\end{array}$ & $\begin{array}{c}0.0048 \\
(0.0044)\end{array}$ \\
\hline Amount & $\begin{array}{l}-0.0165 \\
(0.0530)\end{array}$ & $\begin{array}{l}-0.0166 \\
(0.0529)\end{array}$ & $\begin{array}{l}-0.0167 \\
(0.0527)\end{array}$ \\
\hline Size & $\begin{array}{c}1.2833^{* * *} \\
(0.0689)\end{array}$ & $\begin{array}{l}1.2847^{* * *} \\
(0.0689)\end{array}$ & $\begin{array}{c}1.2888^{* * *} \\
(0.0688)\end{array}$ \\
\hline ROA & $\begin{array}{c}5.0352^{* * *} \\
(1.5642)\end{array}$ & $\begin{array}{c}5.0018^{* * *} \\
(1.5623)\end{array}$ & $\begin{array}{c}4.9415^{* * *} \\
(1.5555)\end{array}$ \\
\hline Leverage & $\begin{array}{c}-5.1029^{* * *} \\
(0.4517)\end{array}$ & $\begin{array}{c}-5.1049^{* * * *} \\
(0.4515)\end{array}$ & $\begin{array}{c}-5.1092^{* * *} \\
(0.4503)\end{array}$ \\
\hline $\mathrm{MtB}$ & $\begin{array}{l}1.0680^{* * *} \\
(0.1197)\end{array}$ & $\begin{array}{l}1.0686^{* * *} \\
(0.1199)\end{array}$ & $\begin{array}{c}1.0706^{* * *} \\
(0.1203)\end{array}$ \\
\hline PPE & $\begin{array}{l}-0.1503 \\
(0.5867)\end{array}$ & $\begin{array}{l}-0.1587 \\
(0.5855)\end{array}$ & $\begin{array}{l}-0.1814 \\
(0.5736)\end{array}$ \\
\hline GdpPerCapita & $\begin{array}{l}-0.0004 \\
(0.0011)\end{array}$ & $\begin{array}{l}-0.0004 \\
(0.0011)\end{array}$ & $\begin{array}{l}-0.0004 \\
(0.0011)\end{array}$ \\
\hline Unemployment & $\begin{array}{c}0.0219 \\
(0.0554)\end{array}$ & $\begin{array}{c}0.0217 \\
(0.0555)\end{array}$ & $\begin{array}{c}0.0213 \\
(0.0553)\end{array}$ \\
\hline Fixed-Effects & & & \\
\hline Year & Yes & Yes & Yes \\
\hline Industry & Yes & Yes & Yes \\
\hline Fit statistics & & & \\
\hline Observations & 6,276 & 6,276 & 6,276 \\
\hline $\mathrm{R}^{2}$ & 0.757 & 0.75698 & 0.75713 \\
\hline Within $\mathrm{R}^{2}$ & 0.58983 & 0.58979 & 0.59005 \\
\hline
\end{tabular}

One-way (Firm) standard-errors in parentheses.

Signif Codes: ***: 0.01, **: 0.05, *: 0.1 
Table 7: Excluding Coastal and Inland Counties

This table presents the results of the ordinary least squares regressions of equation (2), where the bond characteristic of interest is yield spreads, after excluding branches located in certain counties. Specifications (1)-(3) exclude branches located in coastal counties for which there is no expected loss computed in (Hallegatte et al., 2013). Specification (4)-(6) exclude branches located inland. Industry and Year fixed effects are included in all specifications. Standard errors are clustered by issuer.

\begin{tabular}{|c|c|c|c|c|c|c|}
\hline \multirow{2}{*}{$\begin{array}{l}\text { Dependent Variable: } \\
\text { Model: }\end{array}$} & \multicolumn{6}{|c|}{ YieldSpread } \\
\hline & (1) & (2) & (3) & (4) & $(5)$ & (6) \\
\hline \multicolumn{7}{|l|}{ Variables } \\
\hline NoCoastalSLR_Sales & $\begin{array}{c}1.7478^{* * *} \\
(0.6595)\end{array}$ & & & & & \\
\hline NoCoastalSLR_Employ & & $\begin{array}{l}3.3780^{*} \\
(1.9914)\end{array}$ & & & & \\
\hline NoCoastalSLR_Branch & & & $\begin{array}{l}5.3231^{*} \\
(3.0191)\end{array}$ & & & \\
\hline NoInlandSLR_Sales & & & & $\begin{array}{c}1.7622^{* * *} \\
(0.6642)\end{array}$ & & \\
\hline NoInlandSLR_Employ & & & & & $\begin{array}{l}3.3878^{*} \\
(1.9987)\end{array}$ & \\
\hline NoInlandSLR_Branch & & & & & & $\begin{array}{l}5.2748^{*} \\
(2.9726)\end{array}$ \\
\hline Maturity & $\begin{array}{l}-0.0060 \\
(0.0132)\end{array}$ & $\begin{array}{l}-0.0058 \\
(0.0131)\end{array}$ & $\begin{array}{l}-0.0059 \\
(0.0132)\end{array}$ & $\begin{array}{l}-0.0060 \\
(0.0132)\end{array}$ & $\begin{array}{l}-0.0058 \\
(0.0131)\end{array}$ & $\begin{array}{l}-0.0059 \\
(0.0132)\end{array}$ \\
\hline Amount & $\begin{array}{l}-0.3669 \\
(0.2392)\end{array}$ & $\begin{array}{l}-0.3660 \\
(0.2385)\end{array}$ & $\begin{array}{l}-0.3670 \\
(0.2387)\end{array}$ & $\begin{array}{l}-0.3669 \\
(0.2392)\end{array}$ & $\begin{array}{l}-0.3660 \\
(0.2385)\end{array}$ & $\begin{array}{l}-0.3669 \\
(0.2387)\end{array}$ \\
\hline Size & $\begin{array}{l}-0.2313 \\
(0.1454)\end{array}$ & $\begin{array}{l}-0.2270 \\
(0.1442)\end{array}$ & $\begin{array}{l}-0.2236 \\
(0.1425)\end{array}$ & $\begin{array}{l}-0.2313 \\
(0.1454)\end{array}$ & $\begin{array}{l}-0.2270 \\
(0.1442)\end{array}$ & $\begin{array}{l}-0.2240 \\
(0.1427)\end{array}$ \\
\hline ROA & $\begin{array}{c}-3.1361^{* * *} \\
(0.9040)\end{array}$ & $\begin{array}{c}-3.2300^{* * *} \\
(0.9280)\end{array}$ & $\begin{array}{c}-3.1616^{* * *} \\
(0.9105)\end{array}$ & $\begin{array}{c}-3.1368^{* * *} \\
(0.9040)\end{array}$ & $\begin{array}{l}-3.2301^{* * *} \\
(0.9278)\end{array}$ & $\begin{array}{c}-3.1598^{* * *} \\
(0.9100)\end{array}$ \\
\hline Leverage & $\begin{array}{c}2.5925^{* * *} \\
(0.6559)\end{array}$ & $\begin{array}{c}2.5914^{* * *} \\
(0.6535)\end{array}$ & $\begin{array}{c}2.5797^{* * *} \\
(0.6496)\end{array}$ & $\begin{array}{c}2.5924^{* * *} \\
(0.6559)\end{array}$ & $\begin{array}{c}2.5912^{* * *} \\
(0.6535)\end{array}$ & $\begin{array}{c}2.5803^{* * *} \\
(0.6498)\end{array}$ \\
\hline CreditRating & $\begin{array}{l}-0.1334 \\
(0.0949)\end{array}$ & $\begin{array}{l}-0.1338 \\
(0.0945)\end{array}$ & $\begin{array}{l}-0.1352 \\
(0.0940)\end{array}$ & $\begin{array}{l}-0.1334 \\
(0.0949)\end{array}$ & $\begin{array}{l}-0.1338 \\
(0.0945)\end{array}$ & $\begin{array}{l}-0.1352 \\
(0.0940)\end{array}$ \\
\hline $\mathrm{MtB}$ & $\begin{array}{c}-0.2729^{* * *} \\
(0.0864)\end{array}$ & $\begin{array}{c}-0.2705^{* * *} \\
(0.0856)\end{array}$ & $\begin{array}{c}-0.2683^{* * *} \\
(0.0853)\end{array}$ & $\begin{array}{c}-0.2730^{* * * *} \\
(0.0864)\end{array}$ & $\begin{array}{l}-0.2705^{* * *} \\
(0.0856)\end{array}$ & $\begin{array}{c}-0.2684^{* * *} \\
(0.0854)\end{array}$ \\
\hline PPE & $\begin{array}{l}-0.6004 \\
(0.4234)\end{array}$ & $\begin{array}{l}-0.6138 \\
(0.4313)\end{array}$ & $\begin{array}{l}-0.6257 \\
(0.4393)\end{array}$ & $\begin{array}{l}-0.6005 \\
(0.4234)\end{array}$ & $\begin{array}{l}-0.6136 \\
(0.4312)\end{array}$ & $\begin{array}{l}-0.6240 \\
(0.4390)\end{array}$ \\
\hline GdpPerCapita & $\begin{array}{l}0.0037^{*} \\
(0.0021)\end{array}$ & $\begin{array}{l}0.0036^{*} \\
(0.0021)\end{array}$ & $\begin{array}{l}0.0036^{*} \\
(0.0021)\end{array}$ & $\begin{array}{l}0.0037^{*} \\
(0.0021)\end{array}$ & $\begin{array}{l}0.0036^{*} \\
(0.0021)\end{array}$ & $\begin{array}{l}0.0036^{*} \\
(0.0021)\end{array}$ \\
\hline Unemployment & $\begin{array}{c}-0.2360^{* *} \\
(0.1088)\end{array}$ & $\begin{array}{c}-0.2364^{* *} \\
(0.1086)\end{array}$ & $\begin{array}{c}-0.2362^{* *} \\
(0.1087)\end{array}$ & $\begin{array}{c}-0.2360^{* *} \\
(0.1088)\end{array}$ & $\begin{array}{c}-0.2364^{* *} \\
(0.1086)\end{array}$ & $\begin{array}{c}-0.2361^{* *} \\
(0.1087)\end{array}$ \\
\hline Fixed-Effects & & & & & & \\
\hline Year & Yes & Yes & Yes & Yes & Yes & Yes \\
\hline Industry & Yes & Yes & Yes & Yes & Yes & Yes \\
\hline Fit statistics & & & & & & \\
\hline Observations & 6,276 & 6,276 & 6,276 & 6,276 & 6,276 & 6,276 \\
\hline $\mathrm{R}^{2}$ & 0.45209 & 0.45323 & 0.45276 & 0.4521 & 0.45323 & 0.45274 \\
\hline Within $\mathrm{R}^{2}$ & 0.22286 & 0.22447 & 0.22381 & 0.22287 & 0.22449 & 0.22378 \\
\hline
\end{tabular}

One-way (Firm) standard-errors in parentheses.

Signif Codes: ***: 0.01, **: 0.05, *: 0.1 
Table 8: Placebo Test

This table reports the results from a placebo test, where SLR is assigned to placebo neighboring counties. Placebo counties are the closest neighboring non-coastal counties. Actual counties with SLR exposure are assigned a SLR value of 0 . Neighbor SLR is the resulting SLR exposure, weighted by the fraction of sales, employees and number of branches. Industry and Year fixed effects are included in all specifications. Standard errors are clustered by issuer.

\begin{tabular}{|c|c|c|c|}
\hline \multirow{2}{*}{$\begin{array}{l}\text { Dependent Variable: } \\
\text { Model: }\end{array}$} & \multicolumn{3}{|c|}{ YieldSpread } \\
\hline & (1) & (2) & (3) \\
\hline \multicolumn{4}{|l|}{ Variables } \\
\hline NeighborSLR_Sales & $\begin{array}{l}-6.3001 \\
(9.1650)\end{array}$ & & \\
\hline NeighborSLR_Employ & \multicolumn{3}{|c|}{$\begin{array}{l}-8.2140 \\
(11.071)\end{array}$} \\
\hline NeighborSLR_Branch & & & $\begin{array}{c}0.7851 \\
(9.5833)\end{array}$ \\
\hline Maturity & $\begin{array}{l}-0.0061 \\
(0.0133)\end{array}$ & $\begin{array}{l}-0.0062 \\
(0.0133)\end{array}$ & $\begin{array}{l}-0.0062 \\
(0.0133)\end{array}$ \\
\hline Amount & $\begin{array}{l}-0.3656 \\
(0.2392)\end{array}$ & $\begin{array}{l}-0.3649 \\
(0.2390)\end{array}$ & $\begin{array}{l}-0.3666 \\
(0.2395)\end{array}$ \\
\hline Size & $\begin{array}{l}-0.2365 \\
(0.1460)\end{array}$ & $\begin{array}{l}-0.2381 \\
(0.1456)\end{array}$ & $\begin{array}{l}-0.2353 \\
(0.1456)\end{array}$ \\
\hline ROA & $\begin{array}{c}-3.0099^{* * *} \\
(0.8818)\end{array}$ & $\begin{array}{c}-3.0177^{* * *} \\
(0.8814)\end{array}$ & $\begin{array}{c}-3.0213^{* * *} \\
(0.8871)\end{array}$ \\
\hline Leverage & $\begin{array}{c}2.6205^{* * *} \\
(0.6610)\end{array}$ & $\begin{array}{c}2.6237^{* * *} \\
(0.6627)\end{array}$ & $\begin{array}{c}2.5963^{* * *} \\
(0.6534)\end{array}$ \\
\hline CreditRating & $\begin{array}{l}-0.1330 \\
(0.0949)\end{array}$ & $\begin{array}{l}-0.1324 \\
(0.0948)\end{array}$ & $\begin{array}{l}-0.1338 \\
(0.0948)\end{array}$ \\
\hline $\mathrm{MtB}$ & $\begin{array}{c}-0.2749^{* * *} \\
(0.0864)\end{array}$ & $\begin{array}{c}-0.2765^{* * *} \\
(0.0862)\end{array}$ & $\begin{array}{c}-0.2745^{* * *} \\
(0.0859)\end{array}$ \\
\hline PPE & $\begin{array}{l}-0.5832 \\
(0.4183)\end{array}$ & $\begin{array}{l}-0.5856 \\
(0.4199)\end{array}$ & $\begin{array}{l}-0.5708 \\
(0.4162)\end{array}$ \\
\hline GdpPerCapita & $\begin{array}{l}0.0037^{*} \\
(0.0021)\end{array}$ & $\begin{array}{l}0.0037^{*} \\
(0.0021)\end{array}$ & $\begin{array}{l}0.0037^{*} \\
(0.0021)\end{array}$ \\
\hline Unemployment & $\begin{array}{l}-0.2342^{* *} \\
(0.1088)\end{array}$ & $\begin{array}{l}-0.2335^{* *} \\
(0.1086)\end{array}$ & $\begin{array}{c}-0.2353^{* *} \\
(0.1086)\end{array}$ \\
\hline Fixed-Effects & & & \\
\hline Year & Yes & Yes & Yes \\
\hline Industry & Yes & Yes & Yes \\
\hline Fit statistics & & & \\
\hline Observations & 6,276 & 6,276 & 6,276 \\
\hline $\mathrm{R}^{2}$ & 0.45183 & 0.45198 & 0.45166 \\
\hline Within $\mathrm{R}^{2}$ & 0.22249 & 0.2227 & 0.22226 \\
\hline
\end{tabular}

One-way (Firm) standard-errors in parentheses.

Signif Codes: ***: 0.01, **: 0.05, *: 0.1 
Table 9: Inverse Propensity Weighing

In this table, I present the results from the inverse propensity weighted baseline regression for yield spreads as defined in equation (2). Propensity scores are estimated using a probit regression of the treatment dummy (equal to one if the issuer has above median levels of SLR exposure) with the set control variables (bond maturity, credit rating, amount issued, issuer size, ROA, leverage, MtB, PPE, HQ county GDP per capital, unemployment rate, and a dummy for vulnerable industries). All specifications include year and industry fixed effects, as well as baseline control variables. Standard errors are clustered by issuer.

\begin{tabular}{lccc}
\hline \hline $\begin{array}{l}\text { Dependent Variable: } \\
\text { Model: }\end{array}$ & \multicolumn{3}{c}{ YieldSpread } \\
Variables & $(1)$ & $(3)$ \\
SLR_Sales & $\begin{array}{c}1.250^{* * *} \\
\text { (0.390) }\end{array}$ & & \\
SLR_Employ & & $1.813^{* *}$ & \\
& & $(0.803)$ & \\
SLR_Branch & & & $2.753^{* *}$ \\
& & & $(1.353)$ \\
\hline Controls & Yes & Yes & Yes \\
\hline Fixed-Effects & & & \\
Year & Yes & Yes & Yes \\
Industry & Yes & Yes & Yes \\
\hline Fit statistics & \multicolumn{3}{c}{} \\
Observations & 6,276 & 6,276 & 6,276 \\
$\mathrm{R}^{2}$ & 0.432 & 0.444 & 0.441 \\
\hline
\end{tabular}

One-way (Firm) standard-errors in parentheses.

Signif Codes: ***: 0.01, **: 0.05, *: 0.1 
Table 10: Sea Level Rise and Spatial Dispersion

In this table, I present baseline results relating SLR exposure and yields spreads, after excluding issuers that are in the top deciles of geographic dispersion. Geographic dispersion is proxied by the number of counties in which an issuer has branches. Panel A reports estimates of the baseline regression after excluding issuers in the top decile of geographic dispersion, located in more than 802 U.S. counties. SLR is the exposure to climate change risk at branch locations, weighted by the fraction of sales (SLR_Sales), employees (SLR_Employ) and number of branches (SLR_Branch). Control variables are those specified in the baseline regression (Maturity, Amount, Size, ROA, Leverage, CreditRating, MtB, PPE, GdpPerCapita, and Unemployment). Industry and Year fixed effects are included in all specifications. Standard errors are clustered by issuer.

Panel A: Excluding Geographically Diversified Issuers

\begin{tabular}{lccc}
\hline \hline Dependent Variable: & \multicolumn{3}{c}{ YieldSpread } \\
Model: & $(1)$ & $(2)$ & $(3)$ \\
\hline Variables & \multicolumn{3}{c}{} \\
SLR_Sales & $\begin{array}{c}1.6378^{* * *} \\
\text { (0.6235) }\end{array}$ & & \\
SLR_Employ & & $3.1087^{*}$ & \\
& & $(1.7660)$ & \\
SLR_Branch & & & $4.8005^{*}$ \\
& & & $(2.6882)$ \\
\hline Controls & Yes & Yes & Yes \\
\hline Fixed-Effects & \multicolumn{3}{c}{} \\
Year & Yes & Yes & Yes \\
Industry & Yes & Yes & Yes \\
\hline Fit statistics & \multicolumn{3}{c}{} \\
Observations & 5,646 & 5,646 & 5,646 \\
$\mathrm{R}^{2}$ & 0.46718 & 0.46815 & 0.4677 \\
Within $\mathrm{R}^{2}$ & 0.2364 & 0.23779 & 0.23716 \\
\hline \hline
\end{tabular}

One-way (Firm) standard-errors in parentheses.

Signif Codes: ***: 0.01, **: 0.05, *: 0.1 
Panel B: Sea Level Rise and Spatial Dispersion

\begin{tabular}{|c|c|c|c|}
\hline SLR_Sales & $\begin{array}{c}2.1518^{* * *} \\
(0.8071)\end{array}$ & & \\
\hline NbrCounties $\times$ SLR_Sales & $\begin{array}{l}-0.1301 \\
(0.0799)\end{array}$ & & \\
\hline SLR_Employ & & $\begin{array}{c}3.2043 \\
(1.9690)\end{array}$ & \\
\hline NbrCounties $\times$ SLR_Employ & & $\begin{array}{l}-0.0210 \\
(0.1570)\end{array}$ & \\
\hline SLR_Branch & & & $\begin{array}{l}5.6694^{*} \\
(3.3205)\end{array}$ \\
\hline NbrCounties $\times$ SLR_Branch & & & $\begin{array}{l}-0.3029 \\
(0.2680)\end{array}$ \\
\hline NbrCounties & $\begin{array}{l}-0.0008^{*} \\
(0.0004)\end{array}$ & $\begin{array}{c}-0.0009^{* *} \\
(0.0004)\end{array}$ & $\begin{array}{r}-0.0007^{* *} \\
(0.0003)\end{array}$ \\
\hline Controls & Yes & Yes & Yes \\
\hline \multicolumn{4}{|l|}{ Fixed-Effects } \\
\hline Year & Yes & Yes & Yes \\
\hline Industry & Yes & Yes & Yes \\
\hline \multicolumn{4}{|l|}{ Fit statistics } \\
\hline Observations & 6,276 & 6,276 & 6,276 \\
\hline $\mathrm{R}^{2}$ & 0.459 & 0.45924 & 0.46029 \\
\hline Within $\mathrm{R}^{2}$ & 0.23267 & 0.23301 & 0.2345 \\
\hline \multicolumn{4}{|c|}{$\begin{array}{l}\text { One-way }(\text { Firm }) \text { standard-errors in parentheses. } \\
\text { Signif Codes: } * * *: 0.01, * *: 0.05, *: 0.1\end{array}$} \\
\hline
\end{tabular}


Table 11: Industry Heterogeneity

This table reports the baseline results relating sales-weighted SLR exposure and yields spreads, by industry group. Panel A identifies industries that are know to be vulnerable to climate risk (Agriculture, Food, Business, Communication, Energy, Health Care and Transportation). Panel B reports the baseline results by type of vulnerable industry. All specifications include year fixed effects and baseline control variables (bond maturity, credit rating, amount issued, issuer size, ROA, leverage, MtB, PPE, HQ county GDP per capital and unemployment rate). Standard errors are clustered by issuer.

\section{Panel A: Vulnerable vs Non-Vulnerable Industries}

\begin{tabular}{lcc}
\hline \hline Dependent Variable: & \multicolumn{2}{c}{ YieldSpread } \\
Model: & $(1)$ & $(2)$ \\
Industry: & Vulnerable & Non-Vulnerable \\
\hline Variables & & \\
SLR_Sales & $0.9148^{* *}$ & 2.2172 \\
& $(0.3689)$ & $(3.6752)$ \\
\hline Controls & Yes & Yes \\
\hline Fixed-Effects & & \\
Year & Yes & Yes \\
\hline Fit statistics & & \\
Observations & 1,381 & 4,895 \\
$\mathrm{R}^{2}$ & 0.68403 & 0.31968 \\
Within $\mathrm{R}^{2}$ & 0.65742 & 0.13809 \\
\hline \hline
\end{tabular}

One-way (Firm) standard-errors in parentheses.

Signif Codes: ***: 0.01, **: 0.05, *: 0.1

Panel B: Breakdown by Vulnerable Industry Group

\begin{tabular}{|c|c|c|c|c|c|c|}
\hline $\begin{array}{l}\text { Dependent Variable: } \\
\text { Model: } \\
\text { Industry: }\end{array}$ & $\begin{array}{c}\text { (1) } \\
\text { Agriculture and Food }\end{array}$ & $\begin{array}{c}(2) \\
\text { Business }\end{array}$ & $\begin{array}{c}\text { YieldSpre } \\
(3) \\
\text { Communication }\end{array}$ & $\begin{array}{l}(4) \\
\text { Energy }\end{array}$ & $\begin{array}{c}(5) \\
\text { Health Care }\end{array}$ & $\begin{array}{c}\text { (6) } \\
\text { Transportation }\end{array}$ \\
\hline \multicolumn{7}{|l|}{ Variables } \\
\hline SLR_Sales & $\begin{array}{l}-23.895^{* * *} \\
(7.5454)\end{array}$ & $\begin{array}{l}-17.188^{*} \\
(9.3910)\end{array}$ & $\begin{array}{l}50.593^{* *} \\
(20.548)\end{array}$ & $\begin{array}{c}0.7337^{* * *} \\
(0.1709)\end{array}$ & $\begin{array}{l}-4.4402 \\
(57.196)\end{array}$ & $\begin{array}{l}-26.448^{*} \\
(15.499)\end{array}$ \\
\hline Controls & Yes & Yes & Yes & Yes & Yes & Yes \\
\hline \multicolumn{7}{|l|}{ Fixed-Effects } \\
\hline \multicolumn{7}{|l|}{ Fit statistics } \\
\hline $\begin{array}{l}\text { Observations } \\
\mathrm{R}^{2} \\
\text { Within } \mathrm{R}^{2}\end{array}$ & $\begin{array}{c}180 \\
0.7853 \\
0.76431\end{array}$ & $\begin{array}{c}263 \\
0.69379 \\
0.65319\end{array}$ & $\begin{array}{c}398 \\
0.78564 \\
0.75026\end{array}$ & $\begin{array}{c}401 \\
0.7664 \\
0.74745\end{array}$ & $\begin{array}{c}56 \\
0.87836 \\
0.84728\end{array}$ & $\begin{array}{c}204 \\
0.75902 \\
0.69419\end{array}$ \\
\hline
\end{tabular}

One-way (Firm) standard-errors in parentheses.

Signif Codes: ***: 0.01, **: 0.05, *: 0.1 
Table 12: Climate Change Risk and Investment Horizon

This table reports the baseline regression results for yield spreads as defined in equation (2), by investment horizon. Column (1) presents the results for bonds with maturities below 5 years, column (2) with maturities ranging from 5 to 10 years, column (3) with maturities from 10 to 30 years, and column (4) with maturities longer than 30 years. All specifications include year fixed effects and baseline control variables (bond maturity, credit rating, amount issued, issuer size, ROA, leverage, MtB, PPE, HQ county GDP per capital and unemployment rate). Standard errors are clustered by issuer.

\begin{tabular}{|c|c|c|c|c|}
\hline \multirow{3}{*}{$\begin{array}{l}\text { Dependent Variable: } \\
\text { Model: } \\
\text { Issue Maturity: }\end{array}$} & \multicolumn{4}{|c|}{ YieldSpread } \\
\hline & (1) & (2) & (3) & (4) \\
\hline & $<5$ Years & 5-10 Years & 10-30 Years & $>30$ Years \\
\hline \multicolumn{5}{|l|}{ Variables } \\
\hline SLR_Sales & $\begin{array}{c}13.381 \\
(8.4641)\end{array}$ & $\begin{array}{c}0.9109^{* * *} \\
(0.2365)\end{array}$ & $\begin{array}{c}0.9676 \\
(0.8390)\end{array}$ & $\begin{array}{c}2.2866 \\
(3.6878)\end{array}$ \\
\hline Controls & Yes & Yes & Yes & Yes \\
\hline \multicolumn{5}{|l|}{ Fixed-Effects } \\
\hline Year & Yes & Yes & Yes & Yes \\
\hline Industry & Yes & Yes & Yes & Yes \\
\hline \multicolumn{5}{|l|}{ Fit statistics } \\
\hline Observations & 1,592 & 3,183 & 3,555 & 771 \\
\hline $\mathrm{R}^{2}$ & 0.32903 & 0.65004 & 0.29965 & 0.30681 \\
\hline Within $\mathrm{R}^{2}$ & 0.18794 & 0.62476 & 0.21771 & 0.26721 \\
\hline
\end{tabular}

One-way (Firm) standard-errors in parentheses.

Signif Codes: ***: 0.01, **: 0.05, *: 0.1 